\title{
¿Review
}

\section{Potential of Enzymomics Methodologies to Characterize Disease-Related Protein Functions}

\author{
Toru Komatsu ${ }^{a, b}$ \\ ${ }^{a}$ The University of Tokyo Graduate School of Pharmaceutical Sciences; 7-3-1 Hongo, \\ Bunkyo-ku, Tokyo 113-0033, Japan: and ${ }^{b}$ Precursory Research for Embryonic Science and \\ Technology (PRESTO) Investigator; Japan Science and Technology Agency (JST); \\ 4-1-8 Honcho Kawaguchi, Saitama 332-0012, Japan.
}

Received February 14, 2017

\begin{abstract}
Enzymatic functions are often altered during disease onset and progression, and therefore chemicalbiological studies, which utilize chemical knowledge to discover novel protein functions, are often employed to find proteins with functions closely related to disease phenotypes. Such studies are known as forward chemical-biological approaches and form part of the emerging field of enzymomics (omics of enzymes). This review provides an overview of methodologies available for discovering and characterizing disease-related alterations of enzymatic functions and prospects for the future.
\end{abstract}

Key words chemical biology; fluorescent probe; enzyme; enzymomics; peptide

\section{Introduction}

Cellular functions are mediated by a great variety of enzymes, and altered enzymatic functions are often observed during disease onset and progression. Therefore, understanding the functions of enzymes, especially those related to diseases, is the key to developing novel diagnostic methods, as well as therapeutic drugs. ${ }^{1)}$ An example of the importance of linking the functions of specific enzymes to disease-related molecular functions for drug development is provided by the case of dipeptidyl peptidase IV (DPPIV). DPPIV activity was discovered in $1966,{ }^{2)}$ and the enzyme was characterized in the early $1980 \mathrm{~s},{ }^{3,4)}$ but its importance as a drug target for treating type II diabetes was not recognized until 1993, when it was found that DPPIV hydrolytically inactivates the insulinreleasing hormone incretin, i.e., it exhibits incretin hydrolase activity. ${ }^{5}$ This finding stimulated extensive research, focusing mainly on the relationship between DPPIV and diabetes, which eventually led to the development of sitagliptin as the first-in-class DPPIV inhibitor in $2006^{6}$ (Fig. 1).

Thousands of enzymes are present in living systems, and many of their functions are still poorly characterized in terms of their relationship to pathophysiological processes. One reason for this is the difficulty of precisely understanding protein functions, which are dynamic and not as easy to quantify as the levels of DNA, RNA, or proteins in biosamples. Protein functions are also regulated by multiple factors in living systems, including posttranslational modifications (PTMs), protein-protein interactions (PPIs), and intrinsic inhibitors, which makes understanding protein functions in living systems a

This review of the author's work was written by the author upon receiving the 2017 Pharmaceutical Society of Japan Award for Young Scientists. challenging task. ${ }^{1)}$

For understanding protein functions in living systems, small-molecular chemical probes (or drugs) or substrate probes that can control or read out protein functions have proven to be important tools in chemical biology research.7) Many chemical probes to control enzymatic activities have been developed, ${ }^{8)}$ and there are also many substrate probes that allow us to read out the reactions catalyzed by targeted enzymes. Particularly, fluorescent substrate probes, which become fluorescent upon reaction with the target enzymes, are a well-established class of molecules used to study enzymatic activities in living samples, cells, and tissues, ${ }^{9-15)}$ as aids for the diagnosis of diseases, ${ }^{16-18)}$ and as tools to screen for small molecules that modulate enzymatic functions. ${ }^{19-23)}$

The development of chemical tools to study targeted enzymatic functions (reverse chemical-biological approach) has already been extensively reviewed. ${ }^{24-27)}$ Instead, the present review focuses on the rapidly emerging forward chemicalbiological approach, which aims to discover and characterize novel enzymes related to specific phenotypes.

As mentioned above, the functions of proteins are controlled in various ways at the DNA and mRNA levels (e.g., epigenetic controls and alternative splicing) and at the protein level (e.g., PTMs and PPIs), but actual protein function is located downstream of those controls and is the direct process by which proteins govern cellular phenotypes (Fig. 2). In the study of DNA, mRNA, and proteins, omics-type approaches (genomics, transcriptomics, and proteomics) have become important. In those methodologies, the components in biosamples are comprehensively quantified, so that differences between biosamples that can explain altered phenotypes can be identified in relatively nonbiased ways. In particular, high-throughput DNA 


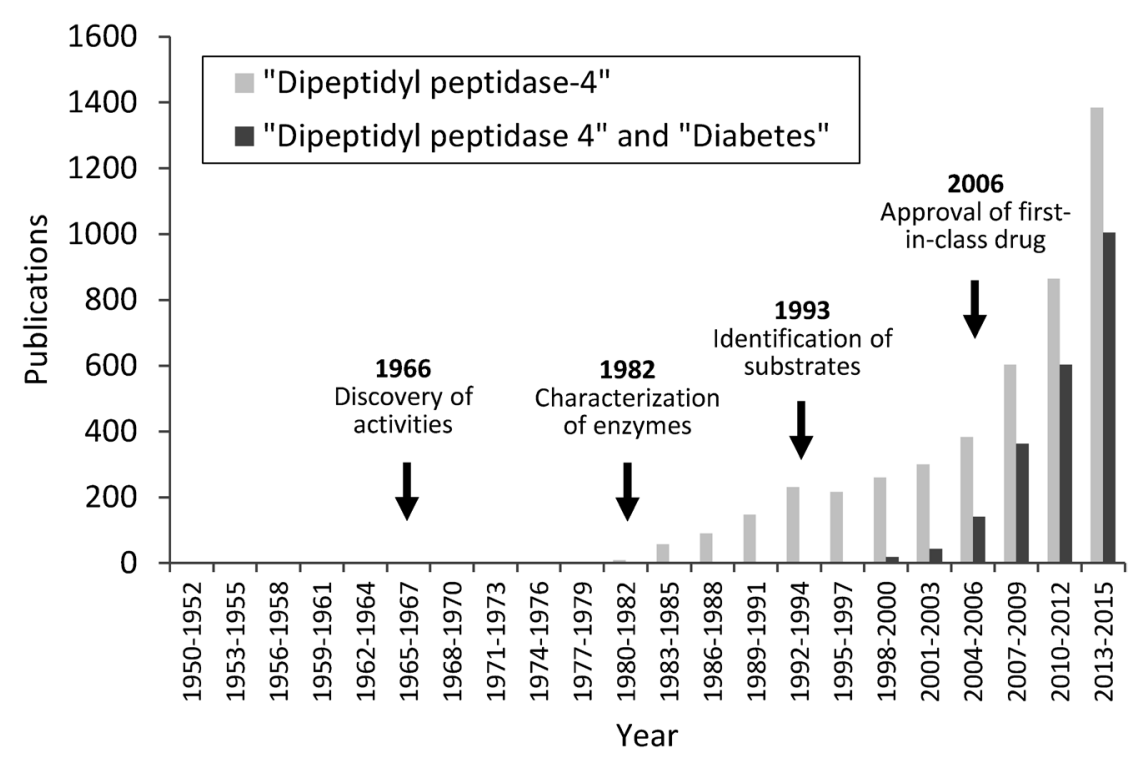

Fig. 1. Numbers of Publications on Dipeptidyl Peptidase-4 (DPPIV) as a Drug Target of Diabetes

Publications with the key word "dipeptidyl peptidase-4" are shown in gray, and those with the key words "dipeptidyl peptidase-4" and "diabetes" are shown in black. The search results are from PubMed (https://www.ncbi.nlm.nih.gov/pubmed/).

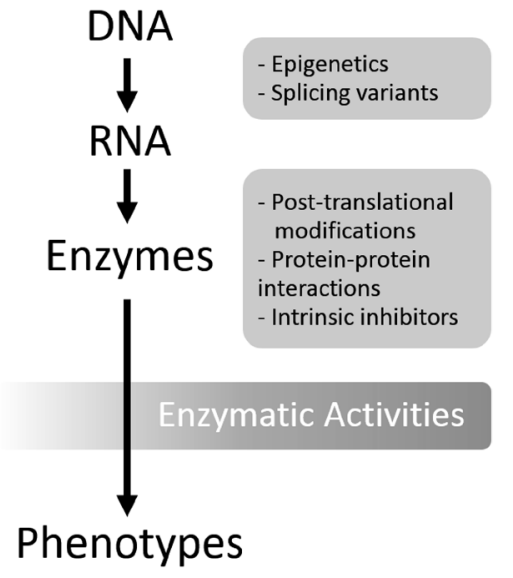

Fig. 2. Various Factors That Influence Cellular Phenotypes

sequencing is widely performed to understand the causes of diseases at the genetic level. ${ }^{28,29)}$ However, differences in cellular functions are not always understandable in terms of changes at the genetic level, because expression of the genome is not directly related to expression of the proteome, ${ }^{30)}$ and altered protein function is not directly related to altered protein expression, as mentioned above. Therefore, an omics approach directly focusing on protein function would be uniquely suit- able for discovering functional changes that are tightly linked to disease phenotypes. The term "enzyme-ome" was defined very recently as "the complete set of enzymes active in a cell at a given time." ${ }^{31)}$ Currently, there is no gold-standard research approach that can cover the whole enzyme-ome, but several interesting methodologies have been established to investigate active enzymatic functions in a relatively global way with the aim of characterizing novel disease-related proteins. This review introduces three representative approaches.

\section{Representative Approaches of Enzymomics Study}

The first approach is to use small molecules that are designed to label covalently only active enzymes in order to detect proteins with desired activities in the proteome. The methodology is termed "activity-based protein profiling (ABPP)," and has been used intensively by Cravatt and Bogyo to study serine and cysteine hydrolases. For example, the fluorophosphonate (FP) group selectively labels active serine hydrolases and has been employed as a general warhead for activity-based serine hydrolase probes. ${ }^{32,33)}$ Labeling of the proteome with an FP-based probe followed by fluorescence detection on electrophoresis gels or enrichment-based proteomic approaches using LC/MS enables the identification of active serine hydrolases. The approach is especially useful to discover disease-related alterations of specific serine hydrolase

\section{Biography}

Toru Komatsu was born in Tokyo, Japan, in 1981. He was awarded a Ph.D. by the University of Tokyo Graduate School of Pharmaceutical Sciences in 2009 (under Prof. Tetsuo Nagano) and during 2009-2011 worked as a postdoctoral fellow at Johns Hopkins University School of Medicine (under Assist. Prof. Takanari Inoue) and at the Scripps Research Institute (under Prof. Benjamin F. Cravatt). He became assistant professor at the University of Tokyo Graduate School of Pharmaceutical Sciences in 2011 (under Prof. Tetsuo Nagano and Prof. Yasuteru Urano). During 2013-2017, he was also a Precursory Research for Embryonic Science and Technology (PRESTO) investigator, Japan Science and Technology Agency (JST). His main research interest is development of chemical-biological tools to discover, characterize, and control enzymatic functions related to the mechanisms of diseases.

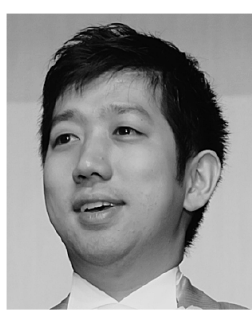

Toru Komatsu 

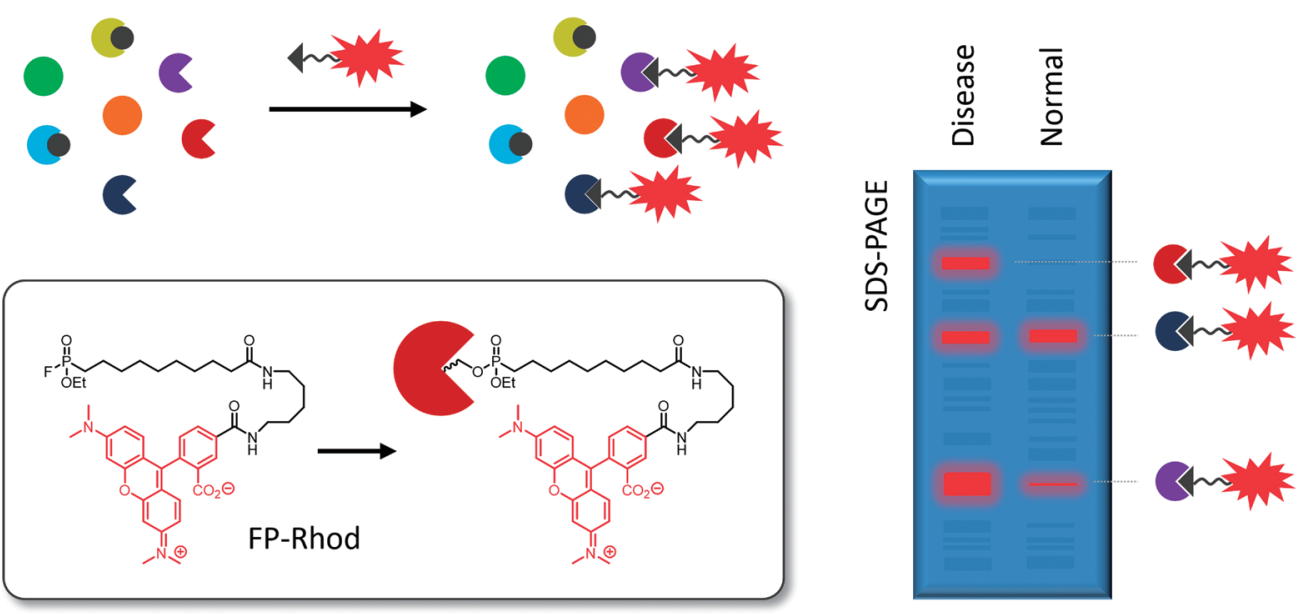

Fig. 3. Schematic Illustration of Activity-Based Protein Profiling of Serine Hydrolases to Discover Disease-Related Enzymatic Functions

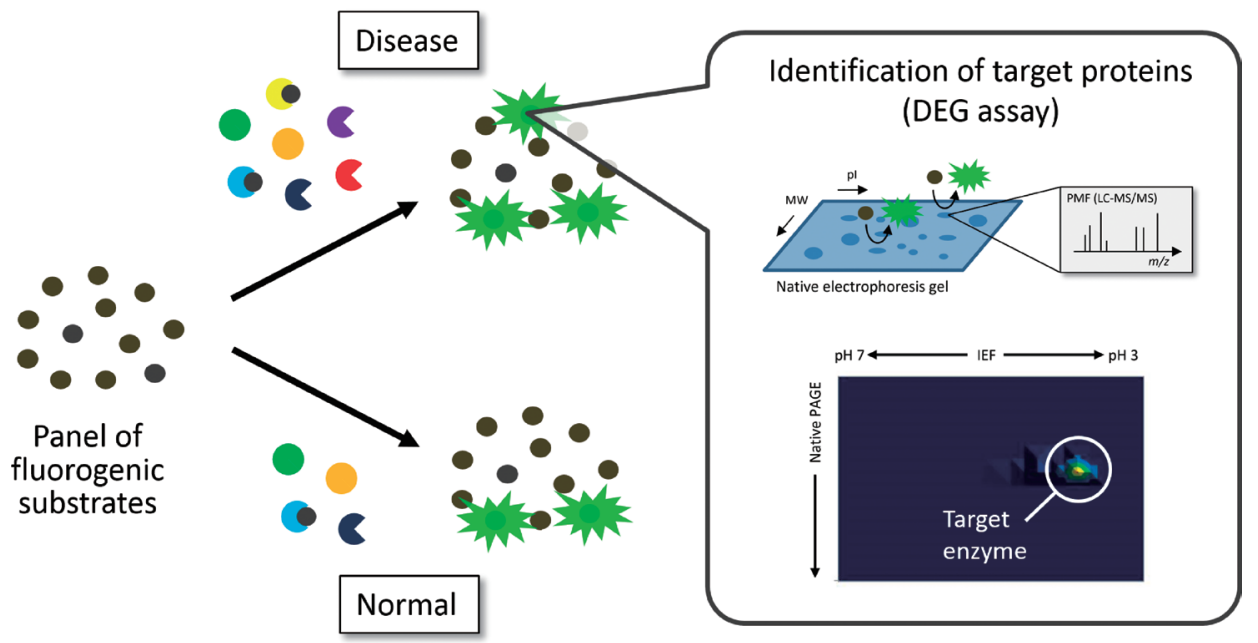

Fig. 4. Enzymomics Approach Using Panels of Fluorogenic Substrates

activities by comparing the labeling patterns of the proteomes in disease and control states (Fig. 3). Also, since the labeling reflects activity, modification of enzymatic activities by small-molecular drugs can be evaluated with the same system, providing valuable information about off-target and on-target effects. ${ }^{34)}$

A representative example is the characterization of monoacylglycerol lipase (MAGL) as a tumor-associated enzyme. ${ }^{35)}$ As a result of FP-based protein labeling to compare the global activity profiles of serine hydrolases between aggressive and nonaggressive tumor cell lines, several enzymes with increased activities only in aggressive tumors were discovered, ${ }^{32)}$ one of which was identified as MAGL. Smallmolecular inhibitors of MAGL were used to identify the metabolic function of this enzyme, and it was concluded that the enzyme regulates a network of pro-tumorigenic lipidsignaling molecules. In addition, the importance of MAGL in the control of endocannabinoid signaling in the brain has been characterized through similar experiments, ${ }^{36,37)}$ and a pharmacological inhibitor of MAGL is currently under clinical trial as an analgesic and antiinflammatory agent.

As exemplified by that study, the methodology provides a powerful means to find enzymes with functionality potentially related to specific diseases among a large number of candi- dates. As described in several reviews, ${ }^{1,38-41)}$ the methodology has become one of the key technologies to assign uncharacterized protein functions in the postgenomic era. Several series of activity-based labeling probes have been developed, and targetable enzyme classes have been extended from serine hydrolases and cysteine hydrolases ${ }^{42-44)}$ to metalloproteinases, ${ }^{45,46)}$ kinases, ${ }^{47,48)}$ phosphatases, ${ }^{49,50)}$ cytochrome P450s, ${ }^{51)}$ and glycosidases. ${ }^{52)}$ Recently, methyltransferases have also become targetable by the development of another activity-based labeling probe resembling the cofactor $S$-adenoylmethionine, ${ }^{53}$ ) and it is now realistic to consider that further development of these systems will allow this strategy to cover most of the major enzyme classes in the enzymome in the near future.

The second approach for enzyme discovery considered here is the autonomous selection strategy. A representative technique is the phage display platform, which can be used to display millions of diverse peptides on the surface of phages in order to screen for strong binders to a target by means of bind-and-enrichment analysis. In usual systems, the basis of the selection is binding to the specified target, but the strategy of screening for increased binding after exposure to a peptide-hydrolyzing activity made the system suitable to find substrate peptides that are preferentially cleaved by the target protease. ${ }^{54,55)}$ Whitney et al. extended this system to perform 
peptidase activity-based selection in transgenic breast cancer model mice in vivo in order to discover proteases of which the activity is highly elevated around tumor areas. ${ }^{56)}$ By careful design in which the target proteases cleave an anionic domain to unmask a cationic domain on phages and thereby facilitate uptake by targeted cells, they were able to enrich phages that are dominantly taken up by targeted sites. They found that the peptide sequence RLQLKL was efficiently cleaved around tumor areas. Biochemical characterization of the activity identified the target protease as elastase, and thus the results indicated that elastase activity is highly elevated around tumor sites. Since the methodology can encompass enormous variations in substrate structure, it should be an efficient way to discover enzymes with altered activities around disease areas. Currently, its scope is limited to cell-surface proteases, but it should be possible to evolve strategies that would be applicable to intracellular enzymes and classes of enzymes other than endopeptidases.

The third strategy for discovering disease-related alterations of enzymatic functions in biosamples is based on the preparation of libraries of substrates, such as fluorescent substrates, that are suitable for high-throughput screening. The idea of using libraries of substrates for bioanalysis is not new, but in contrast with previous research that focused on the characterization of the biochemical features of a single enzyme, ${ }^{57,58)}$ it can be extended to enzymomics study, in which biosamples containing a large number of proteins are screened for multiple enzymatic activities, and potentially interesting activities are picked up. The methodology involves a combination of the discovery of activities and characterizing the responsible enzymes $^{16,59,60)}$ (Fig. 4).

For example, using the fluorescent substrate panel approach, a unique enzymatic function that hydrolyzes formyl methionyl amide was found to be highly elevated in bronchovascular fluids in a mouse model of lung inflammation. ${ }^{61)}$ The target protein was characterized as acylamino acid-releasing enzyme by means of the native electrophoresis-based protein-characterizing methodology termed the "diced electrophoresis gel assay." $59,60,62)$ The result indicates that, in response to lung inflammation, immune cells that exhibit acylamino acid-releasing enzyme (APEH) activity infiltrate into the lung, leading to increased APEH activity in inflammatory bronchoalveolar lavage fluid (BALF). Therefore, APEH activity in BALF could serve as a novel biomarker of immune cell infiltration.

Such substrate-based schemes are promising tools to discover unique enzymatic activities related to specific diseases. However, proper design and choice of substrate scope are extremely important, since they can limit and determine which enzyme classes we can target. For increased comprehensiveness, it will be also important to find ways of preparing ranges of substrates in systemic, nonbiased ways. One of the possible extensions for comprehensive study of bioreactions is the use of systemically prepared libraries of peptides, since a peptide is a suitable platform to monitor multiple bioreactions, such as hydrolysis by exo-/endopeptidases, phosphorylation, glycosylation, methylation, acylation, etc. Recently, one leading example that characterized altered peptide-metabolizing activities to discover novel disease-related enzymatic functions was reported. ${ }^{63)}$ Although the research is at an early stage, it should be possible in the future to extend substratebased comprehensive studies to cover a broad range of bio- chemical reactions.

\section{Conclusion}

This review provides a brief overview of forward chemical biology-based strategies, which can be collectively termed enzymomics, to study disease-related protein functions. At present, available methodologies can cover only limited classes of enzymatic activities. However, other omics fields, especially proteomics and metabolomics, were originally in a similar situation; they started by covering a relatively narrow spectrum of proteins or metabolites, but the evolution of the instruments, sample preparation protocols, and analytical methods dramatically increased their coverage, although they still do not comprehensively cover all proteins or metabolites expected to be present in living systems. In this context, enzymomics is still an emerging field. Nevertheless, it clearly has potential advantages over conventional omics methodologies to discover protein functions that are directly related to disease phenotypes, and this is expected to be enormously helpful for future drug development.

Acknowledgments The research was partially supported by Ministry of Education, Culture, Sports, Science and Technology (MEXT) of Japan (24655147, 15H05371, and $15 \mathrm{~K} 14937$ ) and the JST. The author is also supported by Grants from the Naito Foundation and Mochida Memorial Foundation for Medical and Pharmaceutical Research. The author would like to thank members of Taisha laboratory, especially Prof. Tetsuo Nagano, Prof. Yasuteru Urano, and Assoc. Prof. Kenjiro Hanaoka, and all the collaborators and research friends.

Conflict of Interest The author declares no conflict of interest.

\section{References}

1) Saghatelian A., Cravatt B. F., Nat. Chem. Biol., 1, 130-142 (2005). 2) Hopsu-Havu V. K., Glenner G. G., Histochemie, 7, 197-201 (1966). 3) Fukasawa K. M., Fukasawa K., Hiraoka B. Y., Harada M., Biochim. Biophys. Acta, 657, 179-189 (1981).

4) Püschel G., Mentlein R., Heymann E., Eur. J. Biochem., 126, 359365 (1982).

5) Mentlein R., Gallwitz B., Schmidt W. E., Eur. J. Biochem., 214, 829-835 (1993)

6) Drucker D., Easley C., Kirkpatrick P., Nat. Rev. Drug Discov., 6, 109-110 (2007)

7) Schreiber S. L., Kotz J. D., Li M., Aube J., Austin C. P., Reed J. C. Rosen H., White E. L., Sklar L. A., Lindsley C. W., Alexander B. R., Bittker J. A., Clemons P. A., de Souza A., Foley M. A., Palmer M., Shamji A. F., Wawer M. J., McManus O., Wu M., Zou B., Yu H., Golden J. E., Schoenen F. J., Simeonov A., Jadhav A., Jackson M. R., Pinkerton A. B., Chung T. D., Griffin P. R., Cravatt B. F., Hodder P. S., Roush W. R., Roberts E., Chung D. H., Jonsson C. B., Noah J. W., Severson W. E., Ananthan S., Edwards B., Oprea T. I., Conn P. J., Hopkins C. R., Wood M. R., Stauffer S. R., Emmitte K. A., Brady L. S., Driscoll J., Li I. Y., Loomis C. R., Margolis R. N., Michelotti E., Perry M. E., Pillai A., Yao Y., NIH Molecular Libraries Project Team, Cell, 161, 1252-1265 (2015).

8) Arrowsmith C. H., Audia J. E., Austin C., Baell J., Bennett J., Blagg J., Bountra C., Brennan P. E., Brown P. J., Bunnage M. E., Buser-Doepner C., Campbell R. M., Carter A. J., Cohen P., Copeland R. A., Cravatt B., Dahlin J. L., Dhanak D., Edwards A. M., Frederiksen M., Frye S. V., Gray N., Grimshaw C. E., Hepworth 
D., Howe T., Huber K. V., Jin J., Knapp S., Kotz J. D., Kruger R. G., Lowe D., Mader M. M., Marsden B., Mueller-Fahrnow A., Müller S., O'Hagan R. C., Overington J. P., Owen D. R., Rosenberg S. H., Roth B., Ross R., Schapira M., Schreiber S. L., Shoichet B., Sundström M., Superti-Furga G., Taunton J., Toledo-Sherman L., Walpole C., Walters M. A., Willson T. M., Workman P., Young R. N., Zuercher W. J., Nat. Chem. Biol., 11, 536-541 (2015).

9) Urano Y., Kamiya M., Kanda K., Ueno T., Hirose K., Nagano T., $J$. Am. Chem. Soc., 127, 4888-4894 (2005).

10) Komatsu T., Kikuchi K., Takakusa H., Hanaoka K., Ueno T., Kamiya M., Urano Y., Nagano T., J. Am. Chem. Soc., 128, 15946-15947 (2006).

11) Fujikawa Y., Urano Y., Komatsu T., Hanaoka K., Kojima H., Terai T., Inoue H., Nagano T., J. Am. Chem. Soc., 130, 14533-14543 (2008).

12) Rodriguez P. C., Yee D. J., Sames D., ACS Chem. Biol., 5, $1045-$ 1052 (2010)

13) Kushida Y., Hanaoka K., Komatsu T., Terai T., Ueno T., Yoshida K., Uchiyama M., Nagano T., Bioorg. Med. Chem. Lett., 22, 3908-3911 (2012).

14) Sasakura K., Hanaoka K., Shibuya N., Mikami Y., Kimura Y., Komatsu T., Ueno T., Terai T., Kimura H., Nagano T., J. Am. Chem. Soc., 133, 18003-18005 (2011).

15) Ichikawa Y., Kamiya M., Obata F., Miura M., Terai T., Komatsu T., Ueno T., Hanaoka K., Nagano T., Urano Y., Angew. Chem. Int. Ed. Engl., 53, 6772-6775 (2014).

16) Onoyama H., Kamiya M., Kuriki Y., Komatsu T., Abe H., Tsuji Y., Yagi K., Yamagata Y., Aikou S., Nishida M., Mori K., Yamashita H., Fujishiro M., Nomura S., Shimizu N., Fukayama M., Koike K., Urano Y., Seto Y., Sci. Rep., 6, 26399 (2016).

17) Urano Y., Sakabe M., Kosaka N., Ogawa M., Mitsunaga M., Asanuma D., Kamiya M., Young M. R., Nagano T., Choyke P. L., Kobayashi H., Sci. Transl. Med., 3, 110-119 (2011).

18) Weissleder R., Science, 312, 1168-1171 (2006).

19) Kimura Y., Komatsu T., Yanagi K., Hanaoka K., Ueno T., Terai T., Kojima H., Okabe T., Nagano T., Urano Y., Angew. Chem. Int. Ed. Engl., 56, 110-119 (2016).

20) Kawaguchi M., Okabe T., Okudaira S., Hanaoka K., Fujikawa Y., Terai T., Komatsu T., Kojima H., Aoki J., Nagano T., J. Am. Chem. Soc., 133, 12021-12030 (2011).

21) Sakamoto H., Egashira S., Saito N., Kirisako T., Miller S., Sasaki Y., Matsumoto T., Shimonishi M., Komatsu T., Terai T., Ueno T., Hanaoka K., Kojima H., Okabe T., Wakatsuki S., Iwai K., Nagano T., ACS Chem. Biol., 10, 675-681 (2015).

22) Komatsu T., Takeda A., Hanaoka K., Terai T., Ueno T., Tada Y., Nagano T., Urano Y., Chem. Commun., 50, 15894-15896 (2014).

23) Hanaoka K., Sasakura K., Suwanai Y., Toma-Fukai S., Shimamoto K., Takano Y., Shibuya N., Terai T., Komatsu T., Ueno T., Ogasawara Y., Tsuchiya Y., Watanabe Y., Kimura H., Wang C., Uchiyama M., Kojima H., Okabe T., Urano Y., Shimizu T., Nagano T., Sci. Rep., 7, 40227 (2017).

24) Komatsu T., Urano Y., Anal. Sci., 31, 257-265 (2015).

25) Edgington L. E., Verdoes M., Bogyo M., Curr. Opin. Chem. Biol. 15, 798-805 (2011).

26) Johnsson N., Johnsson K., ACS Chem. Biol., 2, 31-38 (2007).

27) Johnsson K., Nat. Chem. Biol., 5, 63-65 (2009).

28) DePristo M. A., Banks E., Poplin R., Garimella K. V., Maguire J. R., Hartl C., Philippakis A. A., del Angel G., Rivas M. A., Hanna M., McKenna A., Fennell T. J., Kernytsky A. M., Sivachenko A. Y., Cibulskis K., Gabriel S. B., Altshuler D., Daly M. J., Nat. Genet., 43, 491-498 (2011).

29) Metzker M. L., Nat. Rev. Genet., 11, 31-46 (2010).

30) Zhang B., Wang J., Wang X., Zhu J., Liu Q., Shi Z., Chambers M. C., Zimmerman L. J., Shaddox K. F., Kim S., Davies S. R., Wang S., Wang P., Kinsinger C. R., Rivers R. C., Rodriguez H., Townsend R. R., Ellis M. J., Carr S. A., Tabb D. L., Coffey R. J., Slebos R. J.,
Liebler D. C., Carr S. A., Gillette M. A., Klauser K. R., Kuhn E. Mani D. R., Mertins P., Ketchum K. A., Paulovich A. G., Whiteaker J. R., Edwards N. J., McGarvey P. B., Madhavan S., Wang P., Chan D., Pandey A., Shih I.-M., Zhang H., Zhang Z., Zhu H., Whiteley G. A., Skates S. J., White F. M., Levine D. A., Boja E. S., Kinsinger C. R., Hiltke T., Mesri M., Rivers R. C., Rodriguez H., Shaw K. M., Stein S. E., Fenyo D., Liu T., McDermott J. E., Payne S. H., Rodland K. D., Smith R. D., Rudnick P., Snyder M., Zhao Y., Chen X., Ransohoff D. F., Hoofnagle A. N., Liebler D. C., Sanders M. E., Shi Z., Slebos R. J. C., Tabb D. L., Zhang B., Zimmerman L. J., Wang Y., Davies S. R., Ding L., Ellis M. J. C., Reid Townsend R.; NCI CPTAC, Nature (London), 513, 382-387 (2014).

31) Kahl G., "The Dictionary of Genomics, Transcriptomics and Proteomics," Wiley-Blackwell, Hoboken, NJ, 2015.

32) Chiang K. P., Niessen S., Saghatelian A., Cravatt B. F., Chem. Biol., 13, 1041-1050 (2006).

33) Adam G. C., Sorensen E. J., Cravatt B. F., Nat. Biotechnol., 20, 805-809 (2002).

34) Leung D., Hardouin C., Boger D. L., Cravatt B. F., Nat. Biotechnol., 21, 687-691 (2003)

35) Nomura D. K., Long J. Z., Niessen S., Hoover H. S., Ng S. W., Cravatt B. F., Cell, 140, 49-61 (2010).

36) Liu X., Chen Y., Vickstrom C. R., Li Y., Viader A., Cravatt B. F., Liu Q. S., Sci. Rep., 6, 35829 (2016).

37) Schlosburg J. E., Blankman J. L., Long J. Z., Nomura D. K., Pan B., Kinsey S. G., Nguyen P. T., Ramesh D., Booker L., Burston J. J., Thomas E. A., Selley D. E., Sim-Selley L. J., Liu Q. S., Lichtman A. H., Cravatt B. F., Nat. Neurosci., 13, 1113-1119 (2010).

38) Simon G. M., Cravatt B. F., Nat. Chem. Biol., 4, 639-642 (2008).

39) Nomura D. K., Dix M. M., Cravatt B. F., Nat. Rev. Cancer, 10, 630-638 (2010).

40) Moellering R. E., Cravatt B. F., Chem. Biol., 19, 11-22 (2012).

41) Sadaghiani A. M., Verhelst S. H., Bogyo M., Curr. Opin. Chem. Biol., 11, 20-28 (2007)

42) Goulet B., Sansregret L., Leduy L., Bogyo M., Weber E., Chauhan S. S., Nepveu A., Mol. Cancer Res., 5, 899-907 (2007).

43) Blum G., Mullins S. R., Keren K., Fonovic M., Jedeszko C., Rice M. J., Sloane B. F., Bogyo M., Nat. Chem. Biol., 1, 203-209 (2005).

44) Kato D., Boatright K. M., Berger A. B., Nazif T., Blum G., Ryan C., Chehade K. A., Salvesen G. S., Bogyo M., Nat. Chem. Biol., 1, 33-38 (2005)

45) Saghatelian A., Jessani N., Joseph A., Humphrey M., Cravatt B. F., Proc. Natl. Acad. Sci. U.S.A., 101, 10000-10005 (2004).

46) Sieber S. A., Niessen S., Hoover H. S., Cravatt B. F., Nat. Chem. Biol., 2, 274-281 (2006).

47) Patricelli M. P., Szardenings A. K., Liyanage M., Nomanbhoy T. K., Wu M., Weissig H., Aban A., Chun D., Tanner S., Kozarich J. W., Biochemistry, 46, 350-358 (2007).

48) Zhang C., Kenski D. M., Paulson J. L., Bonshtien A., Sessa G., Cross J. V., Templeton D. J., Shokat K. M., Nat. Methods, 2, 435$441(2005)$.

49) Walls C., Zhou B., Zhang Z. Y., Methods Mol. Biol., 519, 417-429 (2009)

50) Kalesh K. A., Tan L. P., Lu K., Gao L., Wang J., Yao S. Q., Chem. Commun., 46, 589-591 (2010).

51) Wright A. T., Song J. D., Cravatt B. F., J. Am. Chem. Soc., 131, 10692-10700 (2009).

52) Vocadlo D. J., Bertozzi C. R., Angew. Chem. Int. Ed. Engl., 43, 5338-5342 (2004).

53) Horning B. D., Suciu R. M., Ghadiri D. A., Ulanovskaya O. A., Matthews M. L., Lum K. M., Backus K. M., Brown S. J., Rosen H., Cravatt B. F., J. Am. Chem. Soc., 138, 13335-13343 (2016).

54) Atwell S., Wells J. A., Proc. Natl. Acad. Sci. U.S.A., 96, 9497-9502 (1999).

55) Kridel S. J., Sawai H., Ratnikov B. I., Chen E. I., Li W., Godzik A., Strongin A. Y., Smith J. W., J. Biol. Chem., 277, 23788-23793 
(2002).

56) Whitney M., Crisp J. L., Olson E. S., Aguilera T. A., Gross L. A., Ellies L. G., Tsien R. Y., J. Biol. Chem., 285, 22532-22541 (2010).

57) Li H., O'Donoghue A. J., van der Linden W. A., Xie S. C., Yoo E., Foe I. T., Tilley L., Craik C. S., da Fonseca P. C., Bogyo M., Nature (London), 530, 233-236 (2016).

58) Backes B. J., Harris J. L., Leonetti F., Craik C. S., Ellman J. A., Nat. Biotechnol., 18, 187-193 (2000).

59) Yoshioka K., Komatsu T., Hanaoka K., Ueno T., Terai T., Nagano T., Urano Y., Chem. Commun., 52, 4377-4380 (2016).

60) Yoshioka K., Komatsu T., Nakada A., Onagi J., Kuriki Y., Kawagu- chi M., Terai T., Ueno T., Hanaoka K., Nagano T., Urano Y., J. Am. Chem. Soc., 137, 12187-12190 (2015).

61) Komatsu T., Yoshioka K., Hanaoka K., Terai T., Ueno T., Nagano T., Urano Y., Chem. Pharm. Bull., 64, 1533-1538 (2016).

62) Komatsu T., Hanaoka K., Adibekian A., Yoshioka K., Terai T., Ueno T., Kawaguchi M., Cravatt B. F., Nagano T., J. Am. Chem. Soc., 135, 6002-6005 (2013).

63) Onagi J., Komatsu T., Ichihashi Y., Kuriki Y., Kamiya M., Terai T., Ueno T., Hanaoka K., Matsuzaki H., Hata K., Watanabe T., Nagano T., Urano Y., J. Am. Chem. Soc., 139, 3465-3472 (2017). 